\title{
Rebuilding pastoral social-ecological resilience on the Qinghai-Tibetan Plateau in response to changes in policy, economics, and climate
}

\author{
Gongbuzeren $^{1}$, Lynn Huntsinger ${ }^{2}$ and WenJun $\mathrm{Li}^{3}$
}

\begin{abstract}
Economic, policy, and climate changes have profoundly influenced pastoral social-ecological systems on the Tibetan Plateau. Climate change is believed to be leading to increasing extreme weather conditions such as snow disasters and droughts, putting a strain on the rangeland resources herders must have to increase income. Market-based economic reforms and interrelated development policies such as the Rangeland Household Contract Policy, the Ecological Construction Project, and herder settlement Initiatives have increased integration of pastoral regions into modern markets with promotion of tourism, expanded livestock markets, and marketing opportunities for rangeland resources. Although allocating common rangelands to households is the foundation of current rangeland management strategies to achieve these goals, it removes important technologies for coping with high variability in rangeland forage production from the traditional rangeland management portfolio on the Tibetan Plateau. These include shared risk, shared labor, seasonal and yearly herd mobility, and access to diverse areas of rangelands and multiple water sources. Field study of two villages in Guinan County of Qinghai Province, and Ruoergai County of Sichuan Province from 2011 to 2014 found that the villages responded to externally driven policy, economic, and climate changes with an innovative locally adapted quota-based grazing management system that preserves valuable management technologies, conserves rangeland resources, and provides individual opportunities for financial gain. In this way the village social-ecological system has exhibited considerable resiliency, maintaining a form of community governance that functions to manage the rangelands, improve well-being as indicated by livestock productivity, and, according to local perceptions, maintain rangeland condition. The community-based grazing quota system devised by the villages occupies a middle ground between common and individual models for resource use because it focuses more on how to equitably distribute services and utilities from rangelands, instead of how to distribute rangelands.
\end{abstract}

Key Words: community-based grazing quota; community resilience; rangeland social-ecological system; resource right; resource-serviceright

\section{INTRODUCTION}

Pastoral regions worldwide are undergoing rapid, large-scale changes in climate, economic processes, and development policy (Fernández-Giménez et al. 2012, Harris et al. 2016). Changes in social or ecological systems have direct influence on the feedbacks and coevolved relations in coupled rangeland social-ecological systems (Ostrom 2009, Li and Li 2012). For such complex systems, resilience thinking suggests that changes or crises may act to trigger social mobilization, open up opportunities for reevaluating the current situation, encourage drawing on sources of experience and knowledge for learning, and spark novelty and innovation (Folke et al. 2010). The pastoral region of China's Qinghai-Tibetan Plateau (QTP) has been influenced by national development policy, climate change, and economic shifts in recent years (Wang et al. 2014, Harris et al. 2016), including land reform that emphasizes privatization of land-use rights and animal ownership. Understanding how some pastoral communities have adapted in order to build resilience offers insight into how grassroots innovations by pastoral communities might help them cope with rangeland fragmentation (Hobbs et al. 2008), marketization, and other changes. Here we use a case study approach to examine pastoral community innovation and adaptation on the QTP.

The QTP alpine steppe covers approximately 165 million hectares or $42 \%$ of China's grazing lands, providing a home to over 6 million pastoralists and agro-pastoralists (ECOCAHVYB 2016). Livestock grazing is the dominant land use. Critical for water conservation, the QTP is termed "China's Water Tower" because it is the source of China's major rivers including the Yangtze, Yellow, Mekong, and Brahmaputra. The core areas of China's biggest reserves for biodiversity, including for species such as the Tibetan antelope (Pantholops hodgsonii) and snow leopard (Panthera uncia), are located here (Sheehy et al. 2006).

With an average elevation of 3500 meters or more, cool mean annual temperatures, and a short frost-free period, climatic variability and heterogeneity of resource distribution are typical of the QTP (Harris et al. 2015), and have become even more dramatic with recent climate changes. According to Chen et al. (2015), there is a warming trend on the QTP, and the IPCC AR5 predicts a continued trend of slightly increasing surface temperatures for at least up to 2035 (Zhang et al. 2015). Such changes lead to extreme weather and precipitation changes (Wang et al. 2014, Zhang et al. 2015). Similarly, China's "Opening up the West" program, initiated in 1999, has brought higher market integration and regular inputs of external financial and technical resources to efforts to develop a market-based economy for pastoral communities that have been ongoing since the 1980s. Development of the tourism industry, establishment of livestock markets (Gaerrang 2012), encouragement of rural-to-urban migration (Foggin 2011), and exploration of other natural resources are thought to encourage successful development.

Since 2013, President Xi has promoted "Targeted Measures in Rural Poverty Reduction" as a conceptual underpinning for rural

${ }^{1}$ Southwestern University of Finance and Economics, China, ${ }^{2}$ Environmental Science, Policy, and Management, University of California, Berkeley, USA, ${ }^{3}$ Peking University, Beijing, China 
development policy. This effort has initiated a variety of marketbased rural development projects, including herder cooperatives, community collective businesses, tourism developments, and diversified uses of services from rangelands (State Council 2014). These programs build on a series of development policies for the pastoral regions promulgated following the breakup of communes in the 1980s, including the Rangeland Household Contract Policy (RHCP) that allocates formerly common land to households under long-term contracts, the Ecological Construction Project that supports nature-based tourism and ecological reserves, and herder settlement initiatives that promote the settlement and relocation of mobile pastoralists ( $\mathrm{Li}$ and Zhang 2009, Gongbuzeren et al. 2015). These policies are predicated to some extent on the belief that allocation of grazing lands and animals to households will help motivate a balanced relationship between the number of animals and rangeland forage production within a specified and unchanging land unit, and that this will prevent rangeland degradation. At the same time, the policies have a goal of encouraging herders to develop alternative income sources, such as in business or tourism, to improve livelihoods (Li and Zhang 2009, Harris et al. 2016). Finally, they facilitate governmental administration of specific rangeland areas by clarifying and simplifying accountability.

Although considerable division of common rangeland under the RHCP has already taken place as mandated by the central government, it is still ongoing, with the goal of further division of shared rangelands as the foundation of property right reforms undergirding a variety of other development and rangeland conservation policies (State Council 2016, Li et al. 2018). Much has been written about the diverse rangeland management problems and social costs of the division and contracting of common grazing lands to individual households (Behnke et al. 1993, Scoones 1994, Kreutzmann 2011, Li and Huntsinger 2011, Wu et al. 2012, Gongbuzeren, 2017), issues widely debated by Chinese researchers (Dong et al. 2010, Cao et al. 2013, Gongbuzeren et al. 2015, Wang et al. 2015) and not unfamiliar to the government (Ma 2011, MOA 2015). As well as leading to overstocking in some areas as families struggle to improve incomes and living standards on their relatively small pastures, the fragmentation of formerly extensive wildlife habitat has profound implications for numerous species, including some that are notably rare (Mallon and Zhigang 2009). Similar to the situation in many parts of the world, the fragmentation of rangelands has increased costs and reduced flexibility in coping with the variable climate that is characteristic of grazing lands (Hobbs et al. 2008). As a result, some studies have recommended retaining common use of rangelands (Banks 2003, Li and Huntsinger 2011). Common use still took place on approximately $39 \%$ of China's rangelands as of 2014 (MOA 2015), mostly on the QTP, and often on some but not all of a village's grazing areas. In many of these places, allocations to households made on paper via the RHCP have not yet been fully implemented on the ground.

However, neither the privatized rangeland use-rights resulting from household allocations, or common property management, fully address the changing attributes of coupled rangeland socialecological systems today, and there has been little progress so far in treating the social and ecological systems of rangelands as integrated and interdependent (Hruska et al. 2017). Recent changes in the pastoral social-ecological system have started to reshape pastoralist values and priorities for rangeland resources, and have increased the recognized variety of services and utilities that rangelands provide to different groups of people on the QTP. For example, in 2008 the government began supporting programs encouraging individual households to rent out or transfer their individual rangeland use-rights to other herders for grazing (State Council 2008). In 2016, the "Suggestions on Improvement of Ownership Rights, Contractual Rights and Use Rights in Rural Land" was initiated to divide the existing two rights, ownership and contractual use rights, into three rights, ownership, nontradable contractual rights, and tradable contractual use rights (State Council 2016). Such land tenure reform encourages rural herders and farmers to rent their allocated lands to other households for development of large-scale animal husbandry or development of the tourism industry, making rangelands a commodity that households can rent out to earn income (Lai and Li 2012, Gongbuzeren et al. 2016). This also means that some pastoralists are able to rent out their individual grazing parcels and resettle in urban areas to seek additional income sources and economic opportunities.

In addition, development of markets for medicinal herbs in many pastoral regions in recent years means that herders may give up pastoralism and rent out their rangelands while they focus on harvesting and marketing other products, notably caterpillar fungus on the QTP, from their rangelands (Gruschke 2008). National, local, and regional governments have initiated various ecological construction policies including establishing nature reserves and national parks in the pastoral regions, providing government subsidies to herders for protecting rangeland ecosystems, and offering employment opportunities (MEP 2016). These policies and economic changes have diversified the services and utilities that each individual household can obtain from rangelands. Along with marketization and population growth, the value of rangeland resources is increasing, and herder demands for more individuated opportunities and benefits from village rangelands are as a result also increasing (Gongbuzeren et al. 2016). Members of pastoral communities on the QTP, who have collectively used and sustainably managed rangelands for at least a thousand years, may now find themselves with conflicting values and competing priorities for the use of village rangelands.

Today it is apparent that rangelands not only hold significant cultural and ecological values for herders, but offer diverse utilities in modern markets (Gongbuzeren et al. 2016). Many individual herders within communities that still retain some collective use of rangelands have begun to demand division of the land in order to more clearly and transparently benefit from the resources on their particular RHCP-allocated lands. Instead of revisiting the long-running debate whether rangelands should be collectively or individually managed, as Walker et al. (2009) and other studies suggest, development policy might more effectively support incremental and localized adaptive governance, shaped by local residents, that increases social-ecological system resilience within the larger, established central policy context (Armitage et al. 2009, Hruska et al. 2017). We explore how two pastoral communities are adapting the pastoral social-ecological system to support sustained livestock production, foster economic development, and maintain community well-being under conditions of high ecological uncertainty and growing demand for marketization of rangeland resources, by clarifying individual rights to rangeland 
resources among herding households while retaining some shared herding and pasture use. Field-based interviews were used to examine institutional innovations by two villages on the QTP in response to changes in policy, economics, and climate, that aim to protect and clarify individual rights but also rangeland resources during this time of rapid economic development.

\section{METHODS}

\section{Case study areas}

The two study villages are anonymized as $\mathrm{CNH}$ Village, in Guinan County of Qinghai Province, and XR Village, in Ruoergai County of Sichuan Province. CNH Village had 431 households and a population of 2000 Tibetan pastoralists in 2014, with 18 thousand ha of rangelands supporting more than 60 thousand sheep and four thousand yaks. Livestock production was the main household income source. The village is at an elevation of 3200 $\mathrm{m}$ with an annual average temperature of $2.3{ }^{\circ} \mathrm{C}$. Village rangelands are a mix of alpine steppe and alpine desert. Average annual precipitation is $398 \mathrm{~mm}$ while evaporation is $1378 \mathrm{~mm}$, so drought is the most frequent and harmful type of natural disaster in the region. XR Village has 140 households totaling 802 people, with 12 thousand ha of rangeland supporting over 20 thousand sheep and six thousand yak in 2014 . The village is at an elevation of $3500 \mathrm{~m}$ with an annual average temperature of around $1.5^{\circ} \mathrm{C}$. Their rangelands are a mix of alpine meadow and wetland pastures with annual precipitation ranging from $490 \mathrm{~mm}$ to 860 $\mathrm{mm}$. Snow disasters, frost, and heavy rain are the main natural disasters affecting these pastoral herds.

Although the two case villages are located in different rangeland ecosystems, both villages are experiencing rapid marketization. Guinan County was selected as one of the pilot sites for promoting Ecological Animal Husbandry by the Qinghai Provincial Government in 2011. Under this program, the government has encouraged new development of herder cooperatives, livestock feed companies, and livestock trade centers that encourage local herders to engage with intensive animal husbandry and increase their livestock off-take. We were told in 2014 that Guinan County has a total of three big livestock trade centers, two companies working on the development of livestock feed, and a growing number of middlemen trading livestock and dairy products. As is apparent, markets for the livestock industry have increased rapidly in Guinan County, affecting many pastoral communities including $\mathrm{CNH}$ Village.

The pastoral regions of Ruoergai County have been strongly influenced by the recent rapid development of a tourism industry. The pastoral landscape of Ruoergai County is a mosaic of marshes, fens, bogs, wetland meadows, and shallow water, interspersed with low hills and subalpine meadows (Yan et al. 2005), providing a complex and diverse cultural and ecological landscape for tourism. The Ruoergai County government has been promoting wetland nature reserves and the pastoral regions of Ruoergai County for eco-tourism development since 2006. According to an XR Village leader, an average of 20 thousand tourists per day visit Huahu, a famous tourism destination located in the summer pastures of XR Village, on weekends during the peak tourist season. A local hotel owner stated that there are over 200 hotels, ranging from small guesthouses to big luxury hotels, established at the county seat.
Although different and growing markets have brought changes to many aspects of the socioeconomic and ecological systems in $\mathrm{CNH}$ and $\mathrm{XR}$ Villages, livestock production is still the main income source. Historically, common property rights to rangelands supported collective use, with seasonal mobility of livestock and access to extensive common land as the main grazing strategy for coping with spatial and temporal variation in forage supply. Similar to other QTP pastoral communities, both $\mathrm{CNH}$ and XR were under the commune system from the 1950s to the early 1980s. In 1982, under the policy of the Household Production Responsibility System (HPRS), livestock were privatized and allocated to individual households via long-term contracts. Rangelands were left to common use until the early 1990s, when the central government began promoting the Rangeland Household Contract Policy (RHCP), allocating land parcels to each household. In $\mathrm{CNH}$, each household got a paper contract from the local government showing the area and location of the rangeland where the household had individual use rights. But on the ground, the villagers only divided up their winter pasture, and continued community collective use of their spring/ fall and summer pastures. In 2009, CNH Village developed a vernacular grazing quota system (Gongbuzeren and Li 2016) that allowed them to continue common use of summer and spring/fall pastures and to maintain four seasonal livestock migrations each year. Similarly, each household in XR Village got a paper contract from the local government showing the location and area of the rangeland where the household had individual use rights, though in actual practice, the village kept community common use of rangelands with seasonal mobility. In 2009, XR also adapted to the push for fragmentation by developing a community-based grazing quota system (Gongbuzeren et al. 2016) wherein they set limits on the total number of livestock but maintained common use of their rangelands.

To find out how the benefits of traditional grazing technologies like use of shared land might be maintained and continue to support the social-ecological system, while satisfying household demand for clarification of individual property rights to rangelands and the governmental push for individuation, we conducted fieldwork from 2012 to 2014 in the two villages. We explored why the two villages developed grazing quota systems, what the impacts of the quota system were on pastoralist wellbeing as indicated by livestock production, income, and the perceived condition of rangeland ecosystems, and how these new institutions mediate herder access to and control over different rangeland services and utilities. Based on herd size, a stratified sample of 30 village households in each village was selected and in-depth interviews were conducted. The same households were tracked over the three-year study period. Because the first author of this paper is a native Tibetan (from a different area), no translator was needed.

Using semistructured interviews, interviewees were asked about the history of the village and the origins of their grazing strategy, monitoring systems, livestock mortality, livestock numbers, and perceptions of rangeland conditions. The impacts of such grazing quota systems on livestock and herder livelihoods have been analyzed empirically in previous publications (Gongbuzeren et al. 2016, Gongbuzeren and $\mathrm{Li}$ 2016), but here the impacts on livestock mortality, livestock numbers, and rangeland ecosystems are further analyzed as part of the pastoralist social ecological 
system. For impacts on the rangeland ecosystem, we assessed herder's perceptions of changes in vegetation conditions, including vegetation growth, the level of disturbance by the common rodent pika, the area of bare ground, and the number of poisonous plant species. In addition, we developed an analytical framework for our work in order to assess how the grazing quota system is different from other rangeland property right arrangements, and the incentives behind the new system.

\section{Analytical framework}

The literature on adaptability as a means to achieve resilience suggests that management should capture the capacity of a SES to learn, combine experience and knowledge as sources of information, adjust responses to changing external drivers and internal processes, and continue developing within the current stability domain (Berkes et al. 2002). However, many current studies of rangeland management on the QTP and other developing rangeland areas are trapped in the long-running debate over whether rangelands in pastoral areas are better off grazed in common and emphasizing community benefits using traditional technologies that include sharing land, risk, and labor, and strategies of mobility, or allocated to households as part of competitive, individuated private holdings that draw on more direct self-interest to motivate management and economic development. Though in one sense these debates are diametrically opposed, in fact they do have common ground: both focus on how to distribute the rangeland resource itself, with the belief that fully distributing the land provides each household equal opportunity to succeed. The argument that an equal land "right" is equivalent to providing each recipient with what it needs to prosper has been thoughtfully challenged on the basis of the unequal capacity to use the land among households (Ribot and Peluso 2003). However, when considering the changing characteristics of the rangeland social-ecological system, the argument is even more problematic because of the inability to use traditional technologies that are highly adapted to ecological conditions, or because of the inability to clarify individual rights and to protect household benefits that are highly demanded by individual household in the face of market-based economic reforms. In this paper, we take the approach that rather than dividing rangelands to household or community, development approaches should focus more on how to manage the services generated by the rangelands instead of the rangeland resource itself, and that the clarification of a rangeland use-right is only one of many ways to obtain the services provided by rangelands for pastoral households. This is addressed in our analytic framework.

Studies have pointed out that the recognition of coevolved interaction between ecosystems and social systems with tempospatial heterogeneity means management of natural resources is nonlinear, complex, and changing (Li and Huntsinger 2011, Li and $\mathrm{Li}$ 2012). In managing complex natural resources, it is critical to focus on how resource users gain access to and derive sets of services and utilities from environmental goods, and how these are mediated by various institutions operating at scales from the macro to the micro (Leach et al. 1999). Previous publications have pointed out different understandings of property rights in the management of natural resources. Leach et al. (1999) described endowments and entitlements in natural resource management, where endowments refer to the rights and resources that social actors have, whereas environmental entitlements refer to alternative sets of utilities derived from environmental goods and services over which social actors have legitimate effective command and that are instrumental in achieving well-being. Entitlement mapping is the relationship between the endowment set and the entitlement set. Similarly, Ribot and Peluso (2003:153) differentiated access from property rights in land, defining access as "the ability to benefit from things." Although these studies focused more on how institutions at different scales mediate processes of endowment and entitlement mapping, or access to resources, we believe that making a distinction between rights over rangelands, and rights over the services and utilities provided by the rangelands, may offer a new perspective on property rights in rangeland management. Based on the environmental entitlement framework of Leach et al. 1999, we developed an analytical framework (Fig. 1) to analyze how the vernacular communitygrazing quota system helps local herders to gain services from the pastoral social-ecological system.

Fig. 1. An analytical framework. The difference between a resource-right and a resource-service-right is that the former focuses on rangeland as an independent resource, whereas the latter focuses on rangeland as an integrated part of a coevolved, pastoral social-ecological system. The mapping processes of resource-rights and resource-service-rights are mediated by various types of institutions operating at different scales

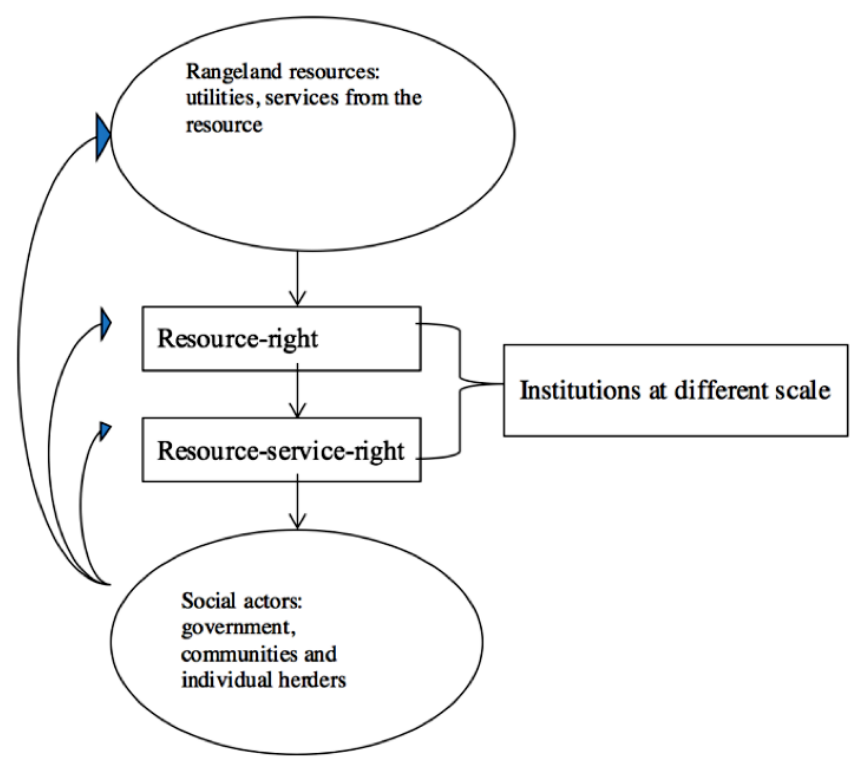

As stated by Leach et al. (1999), we believe that the distribution, quality, and quantity of services and utilities from rangeland resources are influenced by ecological dynamics, which are in part shaped by socioeconomic changes, especially by the recent development of market-based economic reforms in the pastoral regions. Rangeland now provides even more diverse utilities and services to local herders. The relationship between a given social actor, including governments, pastoral communities, and individual herders, and the changing rangeland landscape can be analyzed in terms of the ways different social actors acquire rights 
Fig. 2. Sources of household income in XR and CNH Villages in 2014.

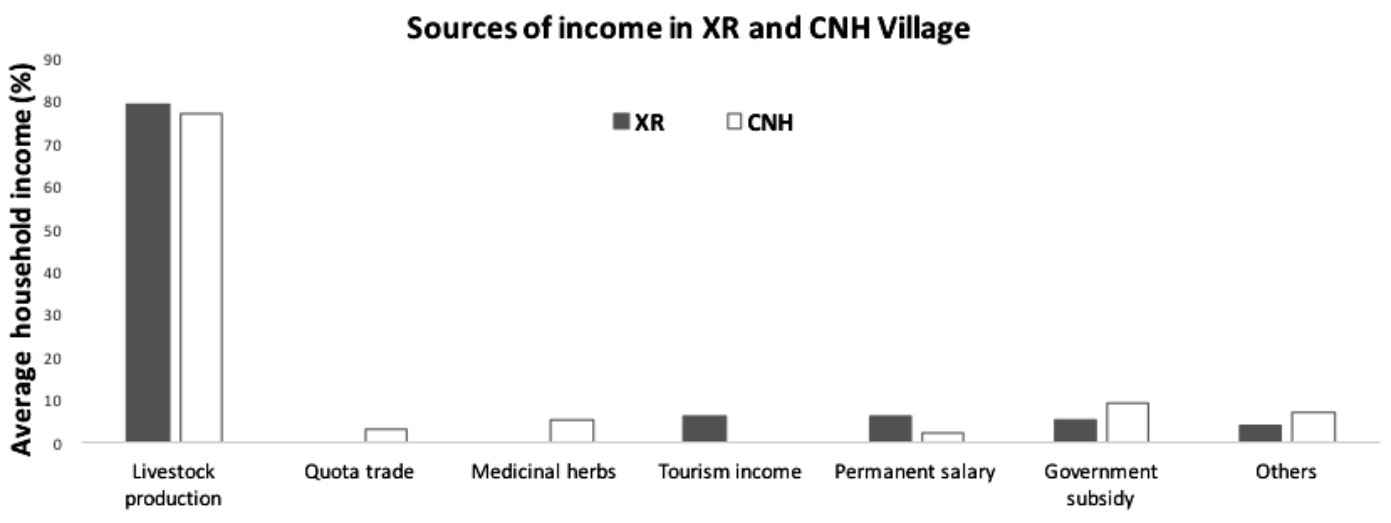

over resources through mapping processes of resource-rights and resource-service-rights. In our framework, a resource-right is defined as the rights that the herders have over rangeland itself, which can be gained through government legitimization or customary rules. For instance, when a rangeland is privatized to an individual household, then the household has access to an area of grazing land, but not to all the services and utilities that a rangeland might provide. On the other hand, a resource-serviceright is defined as the sets of utilities and services derived from rangelands, which are generated through a coevolved pastoral social-ecological system, and over which the herders have legitimate control and access. We believe another major difference between a resource-right and a resource-service-right is that the former focuses on rangeland as an independent resource, while the latter focuses on rangeland as an integrated part of coevolved pastoral social-ecological system. The mapping processes of resource-rights and resource-service-rights are mediated by various types of institutions operating at different scales.

\section{RESULTS}

\section{Why the villages developed a community-based grazing quota system}

Villagers reported that $\mathrm{CNH}$ first applied their quota system in 2009. The village committee annually calculates the total number of livestock owned by village households, and divides it by the total area of all the pastures to assess how many livestock each hectare can support. This becomes the community quota. Households are allocated a share of the quota for livestock numbers matched to the number of hectares allocated on their paper contracts. However, they do not use the summer and spring/ fall range separately. Instead they graze them in common, sharing the unevenly distributed vegetation types and water sources and pooling their labor. Each year, a committee of village leaders and respected elders counts each household's livestock when they migrate to the seasonal pastures. They charge a fee to households whose livestock numbers exceed their grazing quota and distribute the money as compensation to households using less than their quota. The community collectively decides on the amount of the fee. Family illness, lack of family labor, poverty and just plain bad luck can mean that some households have few or no livestock, but their quota entitles them to earn income from these fees.
In XR, herders reported that they estimate the total livestock numbers that their community rangeland can support based on their history of grazing, and equally allocate the total livestock numbers to all herders within the village to derive the individual grazing quota. From 2009 to 2011, the quota was 15 yaks per person, while in 2011-2012, they increased the quota to 18 yaks per person as the herders realized that their rangelands could support more livestock because of improved weather during that period. The community also applied complex monitoring and regulation systems (Gongbuzeren et al. 2016) to ensure that herders followed the rules. Unlike the system in $\mathrm{CNH}$, the quotas are nontradable in XR Village. Instead, they initiated a livestock loan system based on the reciprocal norms that have long been a part of the community. Families without livestock are loaned animals by those with excess numbers, with part of the eventual proceeds going back to the loaner.

The details of the quota system in each village are different. In $\mathrm{CNH}$ Village, individual grazing quotas are decided by a share of the community quota corresponding to the number of hectares allocated on their paper contracts. As a result, individual quotas are different for each of their seasonal pastures, and their quotas change annually based on the total number of livestock owned by the village. In contrast, XR Village's individual grazing quotas are an equal share of the total number of livestock that can be supported by their total rangeland area. Adjustments in the total grazing quota are made in accordance with the condition of village rangelands every year. Another difference is that grazing quotas in CNH Village are tradable within the community, where families pay compensation for exceeding their individual quota. In contrast, in XR, a grazing quota is nontradable, and individual families must adjust their numbers through sale to markets and loaning animals to families that do not have enough livestock to use their quota.

Interviewees offered various explanations for why a grazing quota system was developed in their village (Table 1). Livestock is the most important source of income in both villages (Fig. 2). Prior to the implementation of the grazing quota system, both villages were concerned about unequal use of common pastures and income differentiation. Some households kept increasing numbers of livestock, yet others were unable to build their herds. Over $70 \%$ of the herders in $\mathrm{CNH}$, and $74 \%$ of the herders in XR 
Fig. 3. Household average livestock mortality changes between 2009 and 2014 in XR and CNH Villages. Despite periods of drought, CNH Village did not see an increase in livestock mortality, while in XR Village there was an obvious decline in mortality.
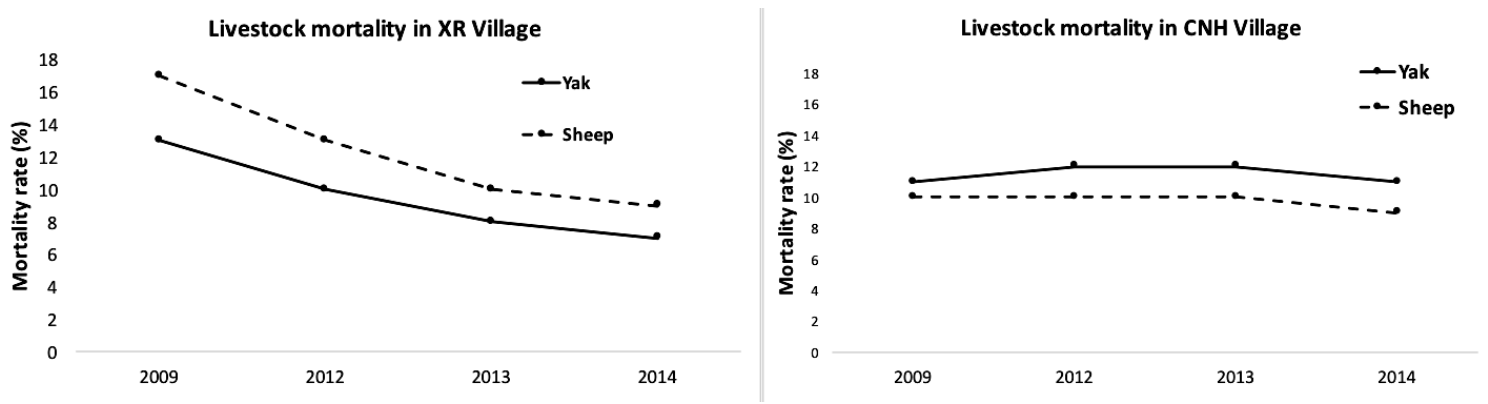

were hoping that grazing rights to their remaining common lands would be clarified and individualized, so that rangeland would become a tradable commodity and the market value of their grazing rights would increase. However, at the same time over $67 \%$ of interviewed XR herders and $85 \% \mathrm{CNH}$ herders wanted to retain collective use of their seasonal rangelands because they recognized the need for access to larger areas to cope with climatic and ecological variability in rangeland production. In addition, even though households had expected, as land reform continued, physical division of their common rangeland into household parcels, and anticipated building wire fences to demarcate the boundaries, over $83 \%$ of XR interviewees and $65 \%$ of $\mathrm{CNH}$ interviewees stated that such a management system would increase conflicts among the community's households. Others stated that dividing rangeland disrupts livestock and wildlife movement in ways that would eventually destroy much of the grassland ecosystem.

Table 1. Herder responses to questions about their reasons for developing a community-based grazing quota system.

\begin{tabular}{lcc}
\hline \hline Factors & $\begin{array}{c}\text { Herder response in } \\
\text { XR } \\
\text { Village (\%) }\end{array}$ & $\begin{array}{c}\text { Herder response in } \\
\text { CNH } \\
\text { Village (\%) }\end{array}$ \\
\hline $\begin{array}{l}\text { Maintain some common use } \\
\text { of rangelands }\end{array}$ & 67 & 85 \\
$\begin{array}{l}\text { Equally distribute rangeland } \\
\text { services }\end{array}$ & 70 & 74 \\
$\begin{array}{l}\text { Control internal conflicts } \\
\begin{array}{l}\text { Provide income for all } \\
\text { Control livestock numbers }\end{array}\end{array}$ & 83 & 65 \\
\hline
\end{tabular}

Although there are many factors that the quota systems have in common, there are other major factors that differ between the two villages. In XR Village, over $83 \%$ of the herders reported that their livestock numbers had increased steadily in the last decade in response to increasing market demand for livestock products, with obvious negative impacts on vegetation and livestock productivity. They wished to control livestock numbers through the grazing quota system. However, this was rarely mentioned in $\mathrm{CNH}$ Village. On the other hand, over $63 \%$ of the herders in $\mathrm{CNH}$ Village stated that around 20 households in their village did not have livestock in 2014, and one benefit of the tradable grazing quota system was that it generated income for families who did not have livestock, or who were very poor.

In short, both villages developed a grazing quota system to retain common use of rangelands despite the push for division, while clarifying rights and achieving more equal distribution of rangeland resources, but the systems were developed by each village and adapted to local conditions. This is in contrast to the one-size-fits-all characteristics of the centrally developed RHCP, and charts an alternative to either fully individuated or common use of rangelands.

\section{Impacts on livestock production}

We assessed impacts on livestock production through changes in livestock numbers and livestock mortality. At the end of 2009 , the grazing quota system was initiated in both villages so we assume the livestock numbers and mortality rates in 2009 were under prequota system management. There has been an obvious decrease in sheep and yak mortality rates in XR Village, where from 2009 to 2014 sheep mortality decreased from $17 \%$ to $9 \%$, and yak mortality decreased from $13 \%$ to $7 \%$ (Fig. 3). In CNH Village, the livestock mortality rate remained relatively unchanged during the same period, but there was a slight decrease in both yak and sheep mortality. A retired CNH Village leader, admittedly invested in the system developed by the village, explained this data by saying the following:
[Because] we are able to control and reduce the village total livestock numbers through our new grazing quota system, our rangeland areas are now sufficient to support our livestock. Although there have been some small-scale droughts in the past few years, we have been able to maintain our seasonal livestock movements and that helps cope with the droughts. We were also able to purchase some fodder from local markets. As a result, we did not see any increase in our livestock mortality.

However, some herders did have concerns: a herder from XR Village said, "as we initiated grazing quota system, I had to reduce my livestock numbers to meet the quota standard, and this affected our income." Another family from the same village stated that "because we are a poor family without any ability to increase livestock numbers and do not have any labor to herd the livestock, we would rather contract the rangelands to an individual household so that we can earn more income from the rangelands." 
Fig. 4. Herder perceptions of changes in vegetation growth (VG), pika disturbance (PD), bare ground (BG), and poisonous species (PS) in XR and CNH Villages from 2009 to 2014.
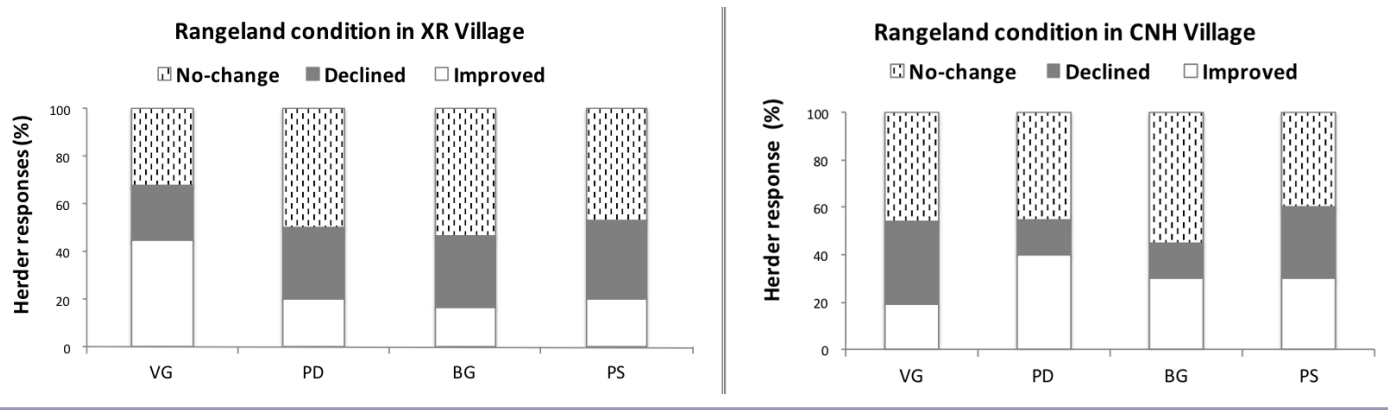

Despite these complaints, all the herders that we interviewed believed that controlling livestock numbers is good for livestock production.

There has been a reduction in household average livestock numbers in 2014 compared to 2009 in both CNH and XR Villages (Table 2). The majority of the herders from both villages stated that controlling livestock numbers after the implementation of the grazing quota system may reduce total livestock numbers but it also reduces livestock mortality so overall livestock production has improved. As reported elsewhere, after implementation of the grazing quota system, $31 \%$ of $\mathrm{CNH}$ Village herders reported that milk production increased in 2012 compared to $41 \%$ in 2014 . In XR Village, 57\% reported an increase in milk production in 2012 compared to $84 \%$ in 2014 (Gongbuzeren et al. 2016). There has been an increase in sheep and a decrease in yaks in both villages. One well known shepherd in XR Village explained the relative increase in sheep by saying, "Because we decided to control total livestock numbers, many families tend to keep more sheep than yaks, because a sheep's life cycle is faster and generates cash income in a shorter time." Although Yak ownership holds more status, in addition to the ability to harvest sheep more frequently, the initial and replacement cost of each animal is much lower. With smaller individual herds, sheep can provide a more frequent and lower risk source of income and food for the household. However, the quota system did not preclude an emphasis on yak production. Some herders from both $\mathrm{CNH}$ and XR Villages maintained their yak numbers, with one stating that "herding sheep requires a high labor investment, and because my family does not have young people to herd the sheep, we kept yaks because yaks provide dairy products in addition to meat. We observed a clear reduction in livestock mortality ...."

\section{Impacts on rangeland ecosystems}

Since the implementation of the community-based grazing quota systems, patterns of grazing movement have been maintained in both villages. According to herder observations, there has not been much change in rangeland condition. In CNH Village, over $35 \%$ of the herders reported a decrease in vegetation growth, but the rest reported an increase or no change (Fig. 4). Similarly, 30 to $40 \%$ of interviewed herders reported an increase in soil disturbance by a common burrowing rodent, the pika, and more bare ground and poisonous species, but the rest reported a decrease or no change. In XR Village, only $23 \%$ of the herders reported a decrease in vegetation growth, while the rest reported an increase or no change. In addition, 17 to $20 \%$ of the herders in XR Village reported an increase in pika soil disturbance, bare ground, and poisonous species respectively, while the rest reported a decrease or no change. Overall, most herders in both villages perceived no changes in rangeland conditions. From this we can conclude that after implementation of the grazing quota system, rangeland conditions as perceived by herders have not worsened.

Table 2. Household average livestock numbers after implementation of the quota system.

\begin{tabular}{cccccccc}
\hline \hline & \multicolumn{3}{c}{ CNH Village } & & \multicolumn{3}{c}{ XR Village } \\
\cline { 2 - 3 } \cline { 6 - 7 } Year & Yak & Sheep & $\begin{array}{c}\text { Total in } \\
\text { sheep units }\end{array}$ & & Yak & Sheep & $\begin{array}{c}\text { Total in sheep } \\
\text { units }\end{array}$ \\
\hline 2009 & 16 & 181 & 260 & & 71 & 148 & 503 \\
2012 & 14 & 198 & 268 & & 55 & 167 & 442 \\
2013 & 12 & 199 & 259 & & 60 & 160 & 460 \\
2014 & 11 & 197 & 252 & & 57 & 173 & 458 \\
\hline
\end{tabular}

\section{DISCUSSION}

By creating a community-based grazing quota system instead of dividing their summer and spring/fall pastures, herders in $\mathrm{CNH}$ and XR Villages have retained the ability to use several traditional grazing management technologies while increasing individual herder resource service rights. They have not observed declines in livestock production and rangeland condition. Using the analytical framework we proposed (Fig. 1), we discuss how the community-based grazing quota system has mediated interactions between local herders and rangeland resources to adapt the changing social-ecological system within the context of externally driven policy change.

Privatizing livestock and contracting rangelands to individual households has been the foundational property rights reform undergirding a variety of other development and rangeland conservation policies in China. The state government continues to define and administer rights to land rather to the services that are generated by the rangelands. However, in a changing socialecological landscape, local herders in our two case studies were able to accommodate both resource-rights and resource-servicerights through innovative management systems.

Instead of managing rights to rangelands as independent resources, the community-based grazing quota system aims to 
manage rights over services and utilities generated by the rangelands as part of an integrated social-ecological system (Fig. 1). It is clear that the services and utilities generated by rangelands have diversified rapidly along with the ongoing socioeconomic changes, and that the local herders' priorities for use of rangelands have become more complex. According to our interviews, herders in $\mathrm{CNH}$ and XR Villages identified the following major, and perhaps contending, priorities for management of their rangelands. First, although there are some families who do not have livestock and rely on alternative income sources, over $77 \%$ of herders in $\mathrm{CNH}$, and $79 \%$ of those in XR, still depend on livestock production for their income and subsistence needs (Fig. 2). Rangeland is critical for supporting livestock production, and much has been written to substantiate the point that livestock production is one of the most viable and efficient forms of land use on the high alpine steppes (Harris et al. 2016). All the interviewees expressed the opinion that sustainable use of rangelands and protecting rangeland ecosystems is a priority for their livelihoods and livestock production.

However, herders stated that since the government began promoting the rangeland transfer system (renting) and neighboring villages started to participate in rangeland rental markets, many poor families with few or no livestock have demanded that common rangelands be contracted to individual households so that they can rent them out to earn income. In addition, promotion of tourism in XR Village has further encouraged herders to demand contracting of rangelands to individual households so that they can rent their rangelands for tourism. In short, the opportunity to rent land out was perceived as a lucrative opportunity for many, creating a demand for change.

Finally, both communities wanted to reduce internal conflicts and maintain community social reciprocity for use of rangelands, and to retain technologies for livestock production such as labor sharing, access to extensive shared land, and patrolling of seasonal pastures. Sharing pastures was widely recognized as an efficient and equitable way to make use of the unevenly distributed resources and temporally variable forage, characteristic of village pastures.

In order to sustain herder access to the diverse services and utilities generated by their rangelands, the community-based grazing quota system applied multiscale institutions. At the individual level, clarification of the grazing quota system, which is tradable among individual households in $\mathrm{CNH}$ and adjusted through a livestock loan system in XR, maintains herder access to resources and controls livestock numbers. This system limits the ability of rich families to expand their livestock numbers, while giving poor families the right to claim compensation from families that exceed their grazing quota. In $\mathrm{CNH}$ Village, individuals are allowed to trade their grazing quota within the community so that poor households have a chance to earn income. In XR, herders are not allowed to trade their quota directly, but a livestock loan system has emerged whereby rich families who have too many animals loan livestock to poor families at prices lower than the market price at the time of the initiation of the loan. The poor families raise the livestock for one year and sell them in the second year, paying the original below market price back to the loaning families in cash with no interest. This has helped poor families to build their livestock without a high initial capital investment. As reported elsewhere the gap between rich and poor in the villages have been reduced since the implementation of grazing quota system (Gongbuzeren et al. 2016, Gongbuzeren and Li 2016). In both villages, the community organization applied traditional monitoring systems. Herders publically took formal, religiouslybased vows to follow the quota system rules. Peer pressure based on local cultural norms was considerable (Gongbuzeren et al. 2016), acting to pressure individual households to follow the system.

At the community scale, maintenance of community collective use of rangelands with seasonal mobility helped to maintain herder access to different rangeland resources in dynamic ecological conditions. In addition, even though rights to a grazing quota are clarified at the individual scale, the rights over how to use and manage the rangelands are held by the community, so they are able to facilitate more flexible management in the face of weather disasters such as snow storms and droughts, and make use of spatial and temporal diversity in forage supply across the landscape. As herders in $\mathrm{CNH}$ stated, even though they now have greater access to livestock feedstuffs in the local region, using natural rangelands with seasonal livestock mobility is preferable because less feed purchase is needed. In addition, CNH Village retains the right to limit individuals to trading their grazing quotas and XR Village retains individual right to limit individuals to initiate livestock loan only within the village so that village resources, and the income from them, are not lost to the village.

Governments may be concerned that administering resource-userights is too complex, compared to simply allocating resources, e.g., allocating land rather than rights of use. At the governmental level, one of the key objectives for contracting rangelands to households is to streamline and clarify accountability and administration. Both communities addressed this through establishment of clear grazing quotas for individual households, and making households accountable for following quota stipulations.

The incentives and social-networks behind these multiscale institutions are very complex. First, the grazing quota system was developed based on each village's remaining collectively used rangelands, such that herders are able to depend on their likewise remaining social reciprocity and kinship networks to facilitate livestock mobility and to share labor in livestock production. Second, grazing quotas can be distributed through market mechanisms, most notably through leasing or loaning, among individual households. Third, even though the grazing quota is clarified at the individual household level, the community facilitates and monitors trading among households. For example, in $\mathrm{CNH}$, the community organization collects compensation funds from the households who exceed their grazing quota system and distributes them to the families who did not exceed their quota at the end of the year. In this way, the community-based grazing quota system is a hybrid institution that applies a combination of community redistribution, social reciprocity and kinship networks, and market mechanisms at multiple scales.

\section{CONCLUSIONS}

Herders in the two case study villages observed that along with socioeconomic changes, the utilities and services generated by the rangelands have diversified rapidly and individual herder's 
priorities for use of rangeland resources are complex. The poor or households without livestock demanded the contracting of rangelands to individual households to provide additional income, while others hoped to maintain community collective use of rangelands to adapt to ecological variability. Herders discovered that as markets for livestock production expanded, many individuals increased their livestock numbers and adversely affected the condition of community rangelands. Addressing this, the two villages initiated community-based grazing quota systems to preserve valuable management technologies, conserve rangeland resources, and provide individual opportunities for financial gain. In this way the village social-ecological system has exhibited considerable resiliency, maintaining a form of community governance that functions to manage the rangelands, improve well-being as indicated by livestock productivity, and, according to local perceptions, maintain rangeland condition.

It can be concluded that the community-based grazing quota system goes beyond the debate over whether rangelands should be contracted to communities or households. Instead, as services and utilities from rangelands have diversified along with vast socioeconomic changes, and herder priorities for use of rangelands have become more complex, these vernacular, adaptive quota systems focus on rights that distribute and maintain herder access to services and utilities generated by rangelands. The communities who initiated quota systems have employed a form of resilience thinking in preserving the adaptability of the traditional common use system, while providing a clarification of individual rights to access rangeland resources, allowing them to be traded and marketed. Therefore, building on the complex and multilevel institutions so richly discussed in other studies (Leach et al. 1999, Ribot and Peluso 2003, Li and Huntsinger 2011), we believe that distinguishing between resource-rights and resource-service-rights can help to develop and understand innovative institutions and property rights arrangements that maintain herder access to services provided by rangelands, and contribute to the development of resilient systems adapted to changes in policy, economics, and climate.

Using an analytical framework we have demonstrated that the community based-grazing quota system is a middle ground between common and individual models for resource use because it focuses more on rights over resource services and utilities generated by the rangelands, instead of rights over rangelands. The communities applied multiscale institutions with complex social networks such as community redistribution, social reciprocity, and market networks to facilitate such innovative management systems.

\section{SPECULATION}

Our cases highlight the potential benefits of focusing on distribution of resource-service-rights mediated by hybrids of market-based and custom-based institutions, in ways that offer new options, a third path between the extremes of complete land division or maintaining all lands in common, for pastoral communities undergoing marketization. Although it might be easier for governments to define rights to rangelands rather than the services generated by the rangelands, future rangeland management policies should acknowledge and promote local innovative institutions that sustain herder access and rights over services generated by rangelands. Facing changing and complex social-ecological systems, greater emphasis on resource-servicerights may improve pastoral community resilience to changes brought by policy, economics, and climate.

At same time, we believe that the community-based grazing quota system is effective on the QTP at least partly because of the area's unique cultural and geographical background. On the QTP, many pastoral communities have been able to preserve their traditional culture, social networks, and traditional ecological knowledge. A strong belief in Buddhism means that taking vows to not violate the grazing quota are a powerful control, and have enabled villages to keep monitoring costs low, one of the important preconditions for successful management of common resources (Ostrom 1990). However, in fast-changing pastoral settings, more studies are needed on documenting and understanding such "third path" responses to land division and their impacts.

Responses to this article can be read online at: http://www.ecologyandsociety.org/issues/responses. php/10096

\section{Acknowledgments:}

This paper was supported by the Natural Science Foundation of China (41671522) and Natural Science Foundation of China Youth Project (71703126), and partly supported by project accession No. CA-B-ECO-0117-MS from the USDA National Institute of Food and Agriculture. We would like to thank Dr. Ian Scoones (IDS at Sussex University) for his useful comments and help in improving the quality of the paper. We thank all the students in the group for their contributions and discussion during our weekly group meeting. And we want to express our deepest gratitude to the local guide and herders who dedicated time and effort to our fieldwork.

\section{LITERATURE CITED}

Armitage, D. R., R. Plummer, F. Berkes, R. I. Arthur, A. T. Charles, I. J. Davidson-Hunt, A. P. Diduck, N. C. Doubleday, D. S. Johnson, M. Marschke, P. McConney, E. W. Pinkerton, and E. K. Wollenberg. 2009. Adaptive co-management for socialecological complexity. Frontiers in Ecology and the Environment 7:95-102. http://dx.doi.org/10.1890/070089

Banks, T. 2003. Property rights reforms in rangeland China: dilemmas on the road to household ranch. World Development 31 (12): 2129-2142. http://dx.doi.org/10.1016/j.worlddev.2003.06.010

Behnke, R. H., I. Scoones, and C. Kerven. 1993. Range ecology at disequilibrium: new models of natural variability and pastoral adaptation in African Savannas. Overseas Development Institute, London, UK.

Berkes, F., J. Colding, and C. Folke, editors. 2002. Navigating social-ecological systems: building resilience for complexity and change. Cambridge University Press, New York, New York, USA. http://dx.doi.org/10.1017/CBO9780511541957

Cao, J., E. T. Yeh, N. M. Hold, Y. Yang, and G. Du. 2013. The effects of enclosures and land-use contracts on rangeland degradation on the Qinghai-Tibetan Plateau. Arid Environment 97:3-8. http://dx.doi.org/10.1016/j.jaridenv.2013.05.002 
Chen, D. L., B Xu, T. Yao, Z. Guo, P. Cui, F. Chen, R. Zhang, X. Zhang, Y. Zhang, J. Fan, Z. Hou, and T. Zhang. 2015. Assessment of past, present and future environmental changes on the Tibetan Plateau. Science China 60(32):3025-3035.

Dong, S. K., L. Wen, L. Zhu, and X. Li. 2010. Implications of coupled natural and human systems in sustainable rangeland ecosystem management in HKH region. Frontiers of Earth Science 4:42-50. http://dx.doi.org/10.1007/s11707-010-0010-Z

Editorial Committee of Chinese Animal Husbandry and Veterinarian Year Book, editors (ECOCAHVYB). 2016. Chinese animal husbandry and veterinarian year book. Chinese Agricultural Publications, Beijing, China.

Fernández-Giménez, G. M., X. Wang, B. Baival, J. A. Klein, and R. S. Reid. 2012. Restoring community connections to the land: building resilience through community-based rangeland management in China and Mongolia. CAB International, Wallingford, UK. http://dx.doi.org/10.1079/9781845938949.0000

Foggin, J. M. 2011. Rethinking "ecological migration" and the value of cultural continuity: a response to Wang, Song, and $\mathrm{Hu}$. Ambio 40:100-101. http://dx.doi.org/10.1007/s13280-010-0105-5

Folke, C., S. R. Carpenter, B. Walker, M. Scheffer, T. Chapin, and J. Rockström. 2010. Resilience thinking: integrating resilience adaptability and transformability. Ecology and Society 15(4):20. http://dx.doi.org/10.5751/ES-03610-150420

Gaerrang. 2012. Alternative development on the Tibetan Plateau: the case of the slaughter renunciation movement. Dissertation. University of Colorado, Boulder, Colorado, USA.

Gongbuzeren. 2017. Herder participation in modern markets: the issues of the credit loan trap. Chapter 5 in A. Ariell, T. Sterberg, and A. Hahn, editors. Pastoralist livelihoods in Asian drylands: environment, governance and risk. White Horse Press, Winwick, UK.

Gongbuzeren, and W. J. Li. 2016. The role of market mechanisms and customary institutions in rangeland management: a case study in Qinghai-Tibet Plateau. Resource Science 31 (10):1637-1647.

Gongbuzeren, Y. Li, and W. Li. 2015. China's rangeland management policy debates: what we have learned? Rangeland Ecology and Management 68:305-314. http://dx.doi.org/10.1016/ j.rama.2015.05.007

Gongbuzeren, M. Zhuang, and W. Li. 2016. Market-based grazing land transfers and customary institutions in the management of rangelands: two case studies on the QinghaiTibetan Plateau. Land Use Policy 57:287-295. http://dx.doi. org/10.1016/j.landusepol.2016.05.035

Gruschke, A. 2008. Nomads without pastures? Globalization, regionalization, and livelihood security of nomads and former nomads in Northern Khams. Journal of the International Association of Tibetan Studies 4:1-40.

Harris, R. B., L. H. Samberg, E. T. Yeh, A. T., Smith, W. Y. Wang, J. B. Wang, Gaerrang, and the late D. J. Bedunha. 2016. Rangeland responses to pastoralists' grazing management on a Tibetan steppe grassland, Qinghai Province, China. Rangeland Journal 38 (1):1-15.
Harris, R. B., W. Wang, Badingqiuying, A. T. Smith, and D. J. Bedunah. 2015. Herbivory and competition of Tibetan steppe vegetation in winter pasture: effects of livestock exclosure and Plateau pika reduction. PLoS ONE 10(7):e0132897. http://dx.doi. org/10.1371/journal.pone.0132897

Hobbs, N. T., K. A. Galvin, C. J. Stokes, J. M. Lackett, A. J. Ash, R. B. Boone, R. S. Reid, and P. K. Thornton. 2008. Fragmentation of rangelands: implications for humans, animals, and landscapes. Global Environmental Change 18(4):776-785. http://dx.doi. org/10.1016/j.gloenvcha.2008.07.011

Hruska, T., L. Huntsinger, M. Brunson, W. Li, N. Marshal, J. L. Oviedo, and H. Whitcomb. 2017. Rangelands as social-ecological systems. Pages 263-302 in D. D. Briske, editor. Rangelands systems: processes, management and challenges. Springer, Cham, Switzerland. http://dx.doi.org/10.1007/978-3-319-46709-2_8

Kreutzmann, H. 2011. Pastoral practices on the move-recent transformations in mountain pastoralism on the Tibetan Plateau. Pages 200-224 in H. Kreutzmann, Y. Yang, and J. Richter, editors. Pastoralism and rangeland management on the Tibetan Plateau in the context of climate and global change. Federal Ministry for Economic Cooperation and Development, Berlin, Germany.

Lai, Y. P., and W. J. Li. 2012. Pasture transfer's impact on Rangeland ecosystem and pastoralists' livelihoods in arid and semi-arid area: a case study in New Barag Right Banner, Hulunbeir. Resource Science 34:1039-1048.

Leach, M., R. Mearns and I. Scoones. 1999. Environmental entitlements: dynamics and institutions in community-based natural resource management. World Development 27(2):225-247. http://dx.doi.org/10.1016/S0305-750X(98)00141-7

Li, W., and L. Huntsinger. 2011. China's grassland contract policy and its impacts on herder ability to benefit in Inner Mongolia: tragic feedbacks. Ecology and Society 16(2):1. http://dx.doi. org/10.5751/ES-03969-160201

Li, W., and Y. Li. 2012. Managing rangeland as a complex system: how government interventions decouples social systems from ecological systems. Ecology and Society 17(1):9. http://dx.doi. org/10.5751/ES-04531-170109

Li, A., J. Wu, X. Zhang, J. Xue, Z. Liu, X. Han, and J. Huang. 2018. China's new rural "separating three property rights" land reform results in grassland degradation: evidence from Inner Mongolia. Land Use Policy 71:170-182. http://dx.doi. org/10.1016/j.landusepol.2017.11.052

Li, W. J., and Q. Zhang. 2009. Understanding rangeland challenges: discovery of rangeland use and management issues at arid and semiarid regions. Economic Science Press, Beijing, China.

Ma, Y. X. 2011. Some suggestion on consummate grassland construct system. China Animal Husbandry 2011(10):40-41.

Mallon, D. P., and J. Zhigang. 2009. Grazers on the plains: challenges and prospects for large herbivores in Central Asia. Journal of Applied Ecology 46:516-519. http://dx.doi.org/10.1111/ j.1365-2664.2009.01654.X

Ministry of Agriculture (MOA). 2015. China Grassland Annual Grassland Monitoring Report. [Translated from the Chinese.] 
MOA, Beijing, China. [online] URL: http://www.moa.gov.cn/ zwllm/jcyj/zh/201504/t20150414_4526567.htm

Ministry of Environmental Protect (MEP). 2016. The $13^{\text {th }}$ Five Year Plan for Environmental Conservation. MEP, Beijing, China.

Ostrom, E. 1990. Governing the commons: the evolution of institutions for collective action. Cambridge University Press, New York, New York, USA. http://dx.doi.org/10.1017/CBO9780511807763

Ostrom, E. 2009. A general framework for analyzing sustainability of social-ecological systems. Science 325:419-422. http://dx.doi.org/10.1126/science.1172133

Ribot, J. C., and N. L. Peluso. 2003. A theory of access. Rural Sociology 68(2):153-181. http://dx.doi.org/10.1111/j.1549-0831.2003. tb00133.x

Scoones, I. 1994. Living with uncertainty: new directions in pastoral development in Africa. Intermediate Technology Publications, London, UK. http://dx.doi.org/10.3362/9781780445335

Sheehy, D. P., D. Miller, D. A Johnson. 2006. Transformation of traditional pastoral livestock systems on the Tibetan steppe. SECHERESSE 17(1-2):142-151.

State Council. 2008. The decision of the central committee of the $C P C$ on rural development and reforms. [Translated from the Chinese.] State Council, Beijing, China. [online] URL: http://sw. mca.gov.cn/article/yw/jczqhsqjs/xzjs/zcwj/201512/20151200878578. $\underline{\text { shtml }}$

State Council. 2014. Establishment of implementation strategies for targeted measures in rural poverty reduction. [Translated from the Chinese.] State Council, Beijing, China. [online] URL: http:// www.cpad.gov.cn/art/2014/5/26/art 50 23765.html

State Council. 2016. Perspectives on further completion of land contract and management rights in agricultural regions of China. [Translated from the Chinese.] State Council, Beijing, China. [online] URL: http://www.gov.cn/xinwen/2016-10/30/content_5126200. $\underline{\mathrm{htm}}$

Walker, B. H., N. Abel, J. M. Anderies, and P. Ryan. 2009. Resilience, adaptability, and transformability in the GoulburnBroken Catchment, Australia. Ecology and Society 14(1):12. http://dx.doi.org/10.5751/ES-02824-140112

Wang, P., J. P. Lassoie, S. J. Morreale, and S. Dong. 2015. A critical review of socioeconomic and natural factors in ecological degradation on the Qinghai-Tibet Plateau, China. Rangeland Journal 37:1-9. http://dx.doi.org/10.1071/RJ14094

Wang, Y., J. Wang, S. Li, and D. Qin. 2014. Vulnerability of the Tibetan pastoral systems to climate and global change. Ecology and Society 19(4):8. http://dx.doi.org/10.5751/ES-06803-190408

Wu, N., Z. L. Yan, and T. Lu. 2012. Enclosure and resettlement in the eastern Tibetan Plateau: dilemma of pastoral development during the last three decades. Pages 291-306 in H. Kreutzmann, editor. Pastoral practices in High Asia: agency of development effect by modernization, resettlement and transformation. Springer, Dordrecht, The Netherlands.
Yan, Z. L., N. Wu, D. Yeshi, and J. Ru. 2005. A review of rangeland privatisation and its implications in the Tibetan Plateau, China. Nomadic Peoples 9(1-2):31-51. http://dx.doi.org/10.3167/082279405781826155

Zhang, X. Z., Y. Y. Ping, P. S. Long, B. W. Kai, W. S. Ping, W. G. Xu, S. Hang, L. T. Xiang, Z. Y. Jian, S. P. Li, L. E. Yuan, S. M. Gen, W. J. Shen, G. Q. Zhu, Z. Y. Li, and O. Y. Hua. 2015. Ecological change on the Tibetan Plateau. Science China Press 60(32):3048-3056. [Translated from the Chinese.] online URL: http://www.xueshu.com/kxtb/201532/920779.html 